\title{
Accounting
}

\section{The moderating role of director's financial expertise in political connections and corporate financial performance in Pakistan}

\author{
Murtaza Masud Niazia*, Zaleha Othmanª and Sitraselvi Chandren ${ }^{\mathrm{b}}$
}

${ }^{a}$ Othman Yeop Abdullah Graduate School of Business, Universiti Utara Malaysia, Malaysia ${ }^{b}$ Tunku Puteri Intan Safinaz School of Accountancy Universiti Utara Malaysia, Malaysia

\begin{tabular}{l}
\hline C H R O N I C L E \\
\hline Article history: \\
Received: November 28, 2020 \\
Received in revised format: \\
December 282020 \\
Accepted: January 26, 2021 \\
Available online: \\
January 26, 2021 \\
\hline Keywords: \\
Political connection \\
Financial performance \\
Directors' financial expertise \\
Political economy \\
Pakistan
\end{tabular}

\section{A B S T R A C T}

Prior theoretical and empirical studies have suggested that political influence affects the application of corporate governance and firm performance enormously. However, several fundamental questions remain to be answered. To fill this knowledge gap, the study's main objectives are examining the direct impact of political connection on firm financial performance in Pakistani non-financial listed companies and the moderating effect of director's financial expertise on political connections and firm financial performance. The study utilised panel data of 220 firms from 2008 to 2017 and used panel corrected standard error regression analysis. The results show that political connection negatively impacted firm financial performance, and director financial expertise as a moderator strengthened the relationship between political connections and firm financial performance. This study's results supported political economy theory in that weak judicial systems and unstable political systems have immense effects on investor's rights. The study contributes to extending the existing literature on political connection by providing evidence of the impact of politically connected firms on firm performance in an emerging market. The study also deliberates on how the director's financial expertise contributes towards the relationship. The findings could be generalised to other countries with similar degrees of development and culture.

\section{Introduction}

Modern corporations have faced numerous challenges for survival in the $21^{\text {st }}$ century. Among the most significant challenges that need more attention are the appropriate education and financial expertise of company directors, particularly at top-level management. Researchers have provided abundant evidence that content knowledge alone is insufficient for hierarchical success, that is, job advancement or upward promotion, and that a unique combination of various capabilities and personality factors is required (Boudreau, Boswell, \& Judge, 2001; Yukl, 2012; Laud et al., 2016). Due to worldwide corporate governance failures and accounting scandals in recent years, interest has grown in studying the role and responsibility of the board of directors in a firm and what tactics companies should use to enhance company performance. Among these tactics is developing linkages with politicians by engaging politicians on the board because companies believe that political connections (POCON) enhance a company's financial performance (FP). Interestingly, past studies have found that the impact of POCON on company FP was both positive and negative (Sokolov \& Solanko, 2016; Dicko, 2016, Wang et al., 2018). For example, empirical evidence has confirmed that POCON positively impacts a company's FP (e.g., Ding et al.., 2014; Unsal, 2017; Wang et al., 2018; Maaloul

* Corresponding author.

E-mail address: murtazaniazi@yahoo.com (M. Masud Niazi) 
et al., 2018).. For example, empirical evidence has confirmed that POCON positively impacts a company's FP (e.g., Ding et al.., 2014; Unsal, 2017; Wang et al., 2018; Maaloul et al., 2018). Politically connected companies have been found to enjoy substantial economic benefits due to systematic exchanges of favours between the companies and politicians (Chaney et al., 2011), a greater likelihood of being bailed out in times of economic distress (Faccio, Masulis, \& McConnell, 2006), more favourable bank lending (Khwaja \& Mian, 2005) and have better competitive positions and greater market power (Faccio, 2006). Conversely, some empirical evidence has found the POCON had a negative impact on company FP and reduced company efficiency (Faccio, 2010; Bliss \& Gul, 2012; Dicko, 2016; Berkman \& Galpoththage, 2017; Habib et al., 2017). Additionally, some researchers also found that the quality of the accounting information provided by politically connected companies was significantly lower than that of their non-connected peers (Chaney et al., 2011). In Pakistani settings, the prior researchers (e.g., Cheema et al., 2016; Saeed et al., 2016; Sadiq et al., 2019) argued that political connections reduced company financial performance. These results provided evidence that engaging politically connected directors (a politician's relative or close friends, government ownership, civil bureaucracy and military bureaucracy) is not that effective in Pakistan. One main reason is that most of these directors were not qualified or had a vested interest in joining these companies. Fan et al. (2007) and Cheema et al. (2016) reported that companies often appointed politically connected directors to serve on the board without any experience, appropriate qualifications or financial expertise but were appointed only based their political background. Therefore, these directors are unable to understand the complexities and dynamics of the markets in most cases that the incompetence of these boards is clearly shown in their decisions.

Some view that director financial expertise is an essential dimension of corporate governance and plays a vital role in governance (Ujunwa, Salami, \& Umar 2013; Osazuwa et al., 2016). That is because an expert and competent and qualified board member can underpin a company's best practices by controlling undue political influence to protect investors and boost their confidence in a company. Such a scenario encouraged an examination of the moderating role of directors' financial expertise with political connections and company financial performance.

\section{Literature Review and Hypothesis Development}

In emerging economies, political connections with companies are widespread (Jaffar \& Abdul-Shakoor, 2016; Sadiq \& Othman, 2017; Idris et al., 2020). Politically connected members often serve on the boards of companies in Pakistan (Faccio, 2010, Cheema et al., 2016; Maaloul et al., 2018; Aldhamari et al., 2020) along with relatives or close friends (Bliss \& Gul, 2012; Cheema et al., 2016) and members of the civil and military bureaucracy (Faccio, 2006; Sadiq \& Othman, 2017). Additionally, government ownership is common (Jaffar \& Abdul-Shakoor, 2016; Sadiq \& Othman, 2017). Therefore, to determine the complete intensity of POCON on firm financial performance, this study incorporated all of the dimensions of POCON (direct and indirect POCON). In this study, director financial expertise was examined as a moderator in relation to POCON and financial performance. The hypotheses development process is explained in detail below.

\subsection{Political connection and firm financial performance}

The abundance of politicians in the corporate sector has created curiosity among researchers and academicians to comprehend the thought-provoking relationship between political connections and firm financial performance (Saeed et al., 2017; Wang et al., 2108; Sadiq et al., 2019). Additionally, prior literature has found that political connections impact firm financial performance, both positively and negatively In terms of political economy theory, if a country has a robust judiciary system, stable political and sound economic system, investors will be more encouraged to invest in companies. Ultimately, this investment will improve a firm's financial performance as companies will have adequate fund to expand the business and enhance productivity and sales. So, the presence of a stable political environment and strong judiciary should have a positive impact of POCON on a company's financial performance. Based on the political economy theory, the helping hand approach occurs when politically connected directors capitalise upon their connections, which is eventually favourable for a company and the entire economy. For instance, some research believes that political connectedness will positively impact company financial performance (e.g., Boubakri, Cosset \& Saffar, 2012; Lashitew, 2014; Maaloul et al., 2018). Some researchers (e.g., Dicko, 2016; Wang et al., 2018) found that politically connected companies have advantages over non-politically connected companies in a stable environment. In this instance, engaging politicians will bring positive changes, and, in turn, these positive changes will enhance the financial performance of a firm. Based on the political economy theory, board priorities are protecting the rights of investors and boosting investor morale. Also, agency theory has suggested that directors should play the role of an agent and work for the principals' best interest (Van Horne \& Wachowicz, 2005). Even though some studies have found positive impacts for politically connected companies on firm financial performance, abundant empirical evidence has shown the negative impacts of POCON on firm financial performance. Certain researchers (Faccio, 2010; Cheema et al., 2016; Aldhamari et al., 2020) believe that political connections do not always work in a firm's favour. For instance, some have found that politically connected companies have low earnings' growth and return on sales (Jackowicz et al., 2014; Sadiq \& Othman, 2017). Sadiq et al. (2019); 
and Aldhamari et al. (2020) provided evidence of poor financial information quality by politically connected companies because of their engagement in accruals based-earning.

In emerging economies like Pakistan, several researchers (for instance, Saeed et al., 2015; Cheema et al., 2016; Sadiq et al., 2019) have found a negative impact of POCON on firm financial performance. These researchers provided two reasons for the negative relationship of POCON with firm performance. First, these listed companies lacked proper control of these politicians, and second, they lacked the capacity to benefit from these political linkages. Based on the political economy theory, stable political and sound judiciary systems are required to take advantage from the political connections. Unfortunately, both are lacking in Pakistan. Moreover, due to political instability, politically connected directors are more inclined towards a gabbinghand approach, rather than prioritising the interests of companies. A high proportion of empirical evidence has found a negative association between POCON and firm FP.

Based on the above arguments, the following hypothesis is posited:

H1: Political connections negatively influence the financial performance (ROE) of a firm.

\subsection{Director Financial Expertise as a Moderator}

The current wave of corporate scandals, for instance, Wells-Fargo (fake account scandal), Volkswagen (the diesel gate scandal), Tesco (accounting irregularities), Patisserie Valerie (illicit overdrafts), and many more scandals have adversely affected the corporate world. In the modern-day corporate world, these financial scandals emphasised the importance of financial experts serving on the board of directors. In response to these scandals, several corporate governance reports (for instance, CalPERS in 1997, Blue Ribbon Commission report in 1998, SOX in 2002 and NYSE in 2004) have been issued. The primary focus of these reports was to recommend parameters and guidelines regarding the financial expertise of board members. According to Sarwar et al. (2018), after the Sarbanes-Oxley Act (SOX) of 2002, companies preferred to have more financial experts on the company board of directors. SOX (Section 407) required the Securities and Exchange Commission (SEC) to issue the rule of financial literacy. According to some researchers (Francis et al., 2012; Johl et al., 2015; Irianto \& Anugerah, 2018), a financial expert and financial literate person is someone who has a degree in accounting or finance or has supervisory expertise (for instance five years' experience in audit or finance or compliance functions). These financially expert directors can play a key role in ensuring transparency, integrity and accountability on a wide range of corporate issues (Johl et al., 2015). Several researchers have studied the association between director financial expertise and firm performance, including Francis et al. (2012); Johl et al. (2015); Shaw et al. (2016); Merendino and Melville (2019); Erin et al. (2019); and Aluoch et al. (2020). These studies have produced mixed findings regarding the association of directors' financial expertise and firm performance. From the positive side, Gunner et al. (2008) stressed that it was important for board members to understand accounting principles and financial statements, which will lead to better board oversight and serve to the better interests of shareholders. Erin et al. (2019) found that the higher the proportion of board members holding degrees in finance-related fields, the higher the performance. Along the same line, Arumona et al. (2019); Harjoto et al. (2019); Swarnodeep and Aurelie (2019); Saidu (2019); and Aluoch et al. (2020) found a positive impact of director financial expertise on firm performance. According to Ettredge et al. (2019), directors with financial expertise are more effective based on resource-based theory. They can perform better on the board, as financial expertise enhances their competencies compared to independent directors. In contrast, when unstable political and weak judicial systems are present, based on political economy theory directors are more inclined towards grabbing-hand approach, the politicians (direct and indirect) and the rest of the management of the company prioritise their self-seeking objectives rather than focusing on a company's overall objectives (De Andres et al., 2020). According to Jaffar and Abdul-Shukoret al. (2016), the grabbing-hand approach suggests that engaging politicians (direct and indirect) on the BOD would influence the company board towards achieving the politicians' political goals of achieving social goals. As a result, it negatively affects a company's financial performance.

In the Pakistani case, the corporate governance codes in 2002, 2012, and 2017 did not address director expertise. Thus, in the Pakistani setting, director financial expertise remains a novel phenomenon. Moreover, little literature exists concerning the relation of POCON and director financial expertise with a company's financial performance. Additionally, the moderating relationship of the director financial expertise between POCON and company FP has not been documented yet in the Pakistani setting. Thus, the present study posits the following hypothesis:

H2: Director financial expertise moderates the relationship between POCON and company financial performance. 


\section{Method}

\subsection{Data and Sample Size}

The population data in this study were non-financial companies listed on the Pakistan Stock Exchange (PSE). The company financial performance and director financial expertise data were collected from annual reports and company websites from 2008 to 2017. The main reason behind selecting ten years period was because of the tenure of two political regimes. The data related to POCON were manually collected from the company annual reports, websites of the companies and Election Commission of Pakistan (ECP) websites (http://www.ecp.gov.pk/). The sample size of this study was 220 non-financial listed companies having a total of 2200 observations. The samples eliminated all financial institutions, companies with missing data for directors, and those companies whose data were missing due to delisting or mergers.

\subsection{Model Specifications}

Two models were developed to achieve the objectives of the study. First, the regression model (Model I) was used to test the direct connexion of POCON on firm FP (ROE) with the control variables of FMSIZE, BIG4, LEVE and INDUS. Second, the regression model (Model II) was employed to examine the moderating effect of director financial expertise on the association between POCON and firm FP (ROE) with control variables including BIG 4, leverage, firm size, Industry effect and year effect.

The regression equations are expressed as follows:

$$
\begin{array}{ll}
\text { Model I } & \operatorname{RoE}_{i t}=\beta_{0}+\beta_{1} \mathrm{PCs}_{\mathrm{it}}+\beta_{2} \mathrm{LEV}_{\mathrm{it}}+\beta_{3} \mathrm{BIG4}_{\mathrm{it}}+\beta_{4} \mathrm{FMSIZE}_{\mathrm{it}}+\beta_{5} \mathrm{INDUS} \mathrm{effect}_{\mathrm{it}}+\beta_{6} \mathrm{YEAR} \mathrm{effect}_{\mathrm{it}}+\varepsilon_{\mathrm{it}} \\
\text { Model II } & \operatorname{RoE}_{i t}=\beta_{0}+\beta_{1} \mathrm{PCs}_{\mathrm{it}}+\beta_{2} \mathrm{DEF}_{\mathrm{it}}+\beta_{3} \mathrm{PCs}_{\mathrm{it}}+\beta_{4} \mathrm{LEV}_{\mathrm{it}}+\beta_{5} \mathrm{FM} \mathrm{SIZE}_{\mathrm{it}}+\beta_{7} \mathrm{INDUS} \mathrm{effect}_{\mathrm{it}}+\beta_{8} \mathrm{YEAR} \mathrm{effect}_{\mathrm{it}}+\varepsilon_{\mathrm{it}}
\end{array}
$$

\subsection{Summary of Variable Measurement and Proxies used in Model I and Mode II}

Table 1 presents a summary of variable measurements and proxies used in this study.

\section{Table 1}

\begin{tabular}{|c|c|c|}
\hline Variable & Measurement & Proxies used in previous studies \\
\hline \multicolumn{3}{|l|}{ Dependent Variable } \\
\hline 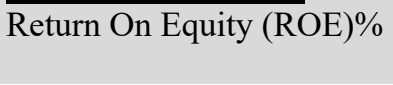 & $\begin{array}{l}\text { Earnings after Taxes / Total } \\
\text { Shareholders' Equity }\end{array}$ & $\begin{array}{l}\text { Buallay et al., 2017; Wang et al., 2018; Hamdan } \\
\text { et al., } 2019\end{array}$ \\
\hline
\end{tabular}

Summary of Variable measurements and proxies

\begin{tabular}{|c|c|c|}
\hline $\begin{array}{l}\text { Independent Variable } \\
\text { Political Connections } \\
\text { (POCON) }\end{array}$ & $\begin{array}{l}\text { POCON is a dummy variable equal to } 1 \\
\text { if a company is POCON and otherwise } \\
\text { equal to } 0 .\end{array}$ & $\begin{array}{l}\text { Cheema et al., 2016; Saeed et al., 2016; Wang } \\
\text { et al., 2018; Sadiq et al., 2019, Idris et al., } 2020\end{array}$ \\
\hline \multicolumn{3}{|l|}{ Moderating Variable } \\
\hline $\begin{array}{l}\text { Director Financial } \\
\text { Expertise's (DFEs) }\end{array}$ & $\begin{array}{l}\text { The number of directors with financial } \\
\text { expertise divided by the total number of } \\
\text { directors on the BoD. }\end{array}$ & Johl et al., 2015; Erin et al., 2019 \\
\hline \multicolumn{3}{|l|}{ Control Variables } \\
\hline Firm Size (FMSIZE) & The natural $\log$ of total assets. & Sokolov \& Solanko, 2016; Ciftci et al., 2019 \\
\hline BIG 4 (BiG4) & $\begin{array}{l}\text { The auditor is a dummy variable equal } \\
\text { to } 1 \text { if the auditor is a Big } 4 \text { audit firm } \\
\text { and } 0 \text { if otherwise. }\end{array}$ & $\begin{array}{l}\text { Juhmani, 2017; Sadiq \& Othman, 2017; Sadiq et } \\
\text { al., } 2019\end{array}$ \\
\hline Leverage (LEV) & $\begin{array}{l}\text { The ratio of total liabilities to total } \\
\text { assets. }\end{array}$ & $\begin{array}{l}\text { Bansal et al., 2016; Khan et al., 2016; Ciftci et } \\
\text { al., } 2019\end{array}$ \\
\hline$\underline{\text { Industry (INDUS) }}$ & $\begin{array}{l}\text { Dummy variable } 1 \text { if the company is } \\
\text { industry and } 0 \text { if otherwise. }\end{array}$ & $\begin{array}{l}\text { Sadiq \& Othman, 2017; Maaloul et al., 2018; } \\
\text { Ciftci et al., } 2019\end{array}$ \\
\hline YEAR effect (YEAR & $\begin{array}{l}\text { A dichotomous variable equal to } 1 \text { if the } \\
\text { company } i \text { in the range of one of these } \\
\text { years }(2008 \text { to } 2017) \text { and } 0 \text { if otherwise. }\end{array}$ & Sadiq \& Othman, 2017 \\
\hline
\end{tabular}




\subsection{Descriptive Statistics}

Table 2 shows the descriptive statistics for all of the variables in the main models of the study. Table 2 shows the minimum, maximum, mean, median, standard deviation skewness, and kurtosis of all the variables. These results were based on 2200 observations (220 firms) and for the ten-year period from 2008 to 2017.

\section{Table 2}

Summary Statistics of the Variables used in the Analysis

\begin{tabular}{|c|c|c|c|c|c|c|c|}
\hline Variable & $\mathbf{N}$ & Mean & SD & Min & Max & Skewness & Kurtosis \\
\hline \multicolumn{8}{|c|}{ Dependent Variables } \\
\hline ROE & 2230 & 10.1157 & 22.4236 & -62.77 & 68.31 & -0.4876 & 4.0240 \\
\hline \multicolumn{8}{|c|}{ Independent Variables } \\
\hline POCON & 2230 & 0.5805 & 0.4935 & 0 & 1 & -0.32643 & 1.1156 \\
\hline \multicolumn{8}{|c|}{ Moderating Variables } \\
\hline DFEs & 2230 & 2.10950 & 0.0979 & 0 & 0.5714 & 1.2482 & 4.9469 \\
\hline \multicolumn{8}{|c|}{ Control Variables } \\
\hline LEVE & 2230 & 0.60444 & 0.30348 & 0.05 & 1.88 & 1.60633 & 6.5197 \\
\hline BIG4 & 2230 & 0.43324 & 0.49564 & 0 & 1 & 0.26944 & 1.1026 \\
\hline FMSIZE & 2230 & 14.5555 & 1.5552 & 9.25 & 20.36 & 0.1029 & 3.6167 \\
\hline
\end{tabular}

Note: ROE represents Return on Equity calculated using Hamdan et al.'s (2019) model. POCON is the proxy of political connection, which contains all five attributes (both direct \& indirect). DFEs represent director financial expertise, LEVE represents leverage, BIG4 is the top four audit firms globally; FMSIZE represents firm size.

\subsubsection{Correlation Matrix and Multicollinearity Test}

Table 3 shows the Pearson correlation matrix where the highest correlation between variables was DEFs moderating variable and the interaction term POCON $\times$ DEFs at 0.677. According to Hair et al. (2006) if the highest value is less than 0.9, this means no multicollinearity issue is present.

Table 3

Pearson's Correlation Matrix (2200 Observations)

\begin{tabular}{|c|c|c|c|c|c|c|c|}
\hline Variables & $(1)$ & $(2)$ & (3) & (4) & $(5)$ & $(6)$ & (7) \\
\hline (1) $\mathrm{ROE}$ & 1.000 & & & & & & \\
\hline (2) POCON & 0.001 & 1.000 & & & & & \\
\hline (3) DFEs & 0.029 & 0.020 & 1.000 & & & & \\
\hline (4) POCON*DFEs & -0.007 & $0.502 * * *$ & $0.677 * * *$ & 1.000 & & & \\
\hline (5) LEVE & $-0.187 * * *$ & -0.022 & $-0.054 * *$ & $-0.088 * * *$ & 1.000 & & \\
\hline (6) BIG4 & $0.240 * * *$ & $0.135 * * *$ & $0.206 * * *$ & $0.195 * * *$ & $-0.229 * * *$ & 1.000 & \\
\hline (7) FMSIZE & $0.217 * * *$ & $0.233 * * *$ & $0.052 * *$ & $0.112 * * *$ & $-0.184 * * *$ & $0.327 * * *$ & 1.000 \\
\hline
\end{tabular}

Notes: ROE represents Return on Equity calculated using Hamdan et al. (2019) model. POCON is the proxy of political connection, which contains all five attributes (both direct \& indirect) DFEs represents director financial expertise, LEVE represents leverage, BIG4 is the top four audit firms in the world; FMSIZE represents firm size. ${ }^{* * *} \mathrm{p}<0.01,{ }^{* *} \mathrm{p}<0.05,{ }^{*} \mathrm{p}<0.10$. Table 1 defines all variables

According to Hamilton (2012), researchers cannot rely entirely on a correlation matrix to detect multicollinearity, and examining the variance inflation factor (VIF) test for collinearity among variables is important. According to Hair et al. (2006), the VIF value should not be greater than 10 to avoid the collinearity issue. This study has no multicollinearity problem, as shown in Table 4 because all values were less than 10 .

Table 4

Standard Tests on VIF Results

\begin{tabular}{cccc}
\hline & VIF & $1 /$ IF & .3 \\
\hline POCON×DFEs & 3.338 & .395 & .528 \\
DEFs & 2.533 & .827 & .839 \\
POCON & 1.893 & .926 \\
\hline FIG4 & 1.21 & 1.192 & 1.08 \\
\hline
\end{tabular}


The current study employed the panel corrected standard error (PCSE) for regression analysis based on the diagnostic tests. Table 5 shows the main model. First, the Breusch and Pagan LM (B\&P LM) test was conducted to decide whether the Pooled OLS or Random Effect Model was appropriate for the present study. The B\&P LM test was rejected as H0, $979.94(0.000) * * *$, $\mathrm{p}<.01$ ), which suggested that Random Effects was a more appropriate model than Pooled OLS. Second, after the B\&P LM test, further clarification required that a decision be made as to whether the fixed model or Random effect model was more appropriate. For that purpose, the Hausman test was conducted. The Hausman test was accepted as $\mathrm{H} 0$ needed clarification and the Hausman test was accepted as H0, $9.93(0.8707, \mathrm{p}>.05)$. The Hausman results demonstrated that the Random Effect Model was more appropriate than the Fixed Effect Model, which means that FEM was not an appropriate model compared to the REM for non-financial listed companies. Finally, further diagnostic tests examined heteroskedasticity and serial correlation problems. Heteroskedasticity and serial correlations issues were rejected at $52630(0.000)^{* * *}$ and $40.048(0.000)^{* * *}$, respectively. Hence, the current study employed the Panel Corrected Standard Error technique. See Table 5.

\section{Table 5}

Main regression results (PCSE) for Model (Dependent Variables= ROE and 2200 Observations)

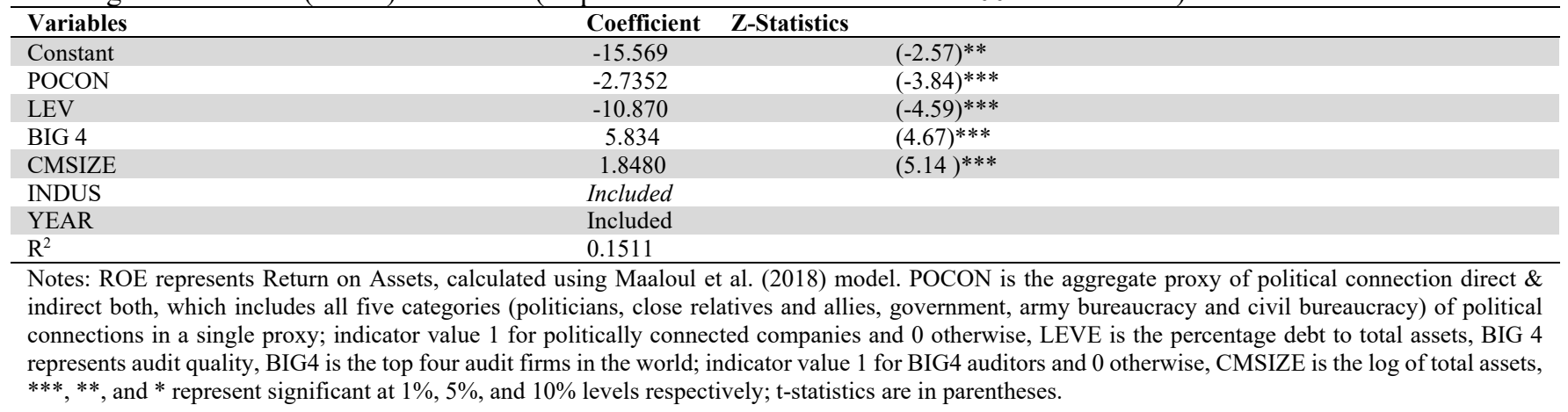

Table 5 indicates that POCON had a negative and $(<0.01)$ significant relationship with ROE. The negative association suggests that companies with political connections perform lower than non-politically connected companies. This result aligns with H1. These results align with Saeed et al. (2016) and Dicko (2018), who concluded that the ROE of politically connected companies was lower than non-politically connected companies. The political economy theory grabbing-hands approach supports the results of the present study. In such a case, management is entrenched, and politically connected directors prefer to engage in activities for their own benefits and establish personal links that could damage the interests of minority shareholders. Moreover, the present results do not align with either agency theory or resource dependency theory. Political directors on the board prioritise their own interests rather than those of the majority shareholders. So, in this kind of setting, the board of directors will lead a company towards agency problems. The board will be unable to use politicians properly as an external resource.

\subsubsection{Sensitivity Test: The Moderating Effect of Director Efficacy}

Table 6 presents the regression model with the director's financial expertise's moderating effect on the association between POCON and ROE). The results in Table 6 indicate that director's financial expertise enhances the negative linkage between political connection and ROE. The result does not support $\mathrm{H}_{2}$; hence, the hypothesis is rejected. The above-stated interaction terms results support the political economy theory. According to political economy theory, if there is a weak judicial, political, and economic system, then the company's directors and management will more be inclined towards the grabbing-hand approach to create personal linkages with these politicians and take personal benefits rather than protect and utilise company resources effectively.

Thus, company's strategy has led to a grabbing-hand approach, which adversely affects the company's financial performance. Moreover, according to Bertrand and Karmarz (2007) and Fan et al. (2007), the primary concern of management in engaging politicians on the board is to establish links with them rather than focus on the financial expertise of these politicians. In emerging economies like Pakistan, company management is well aware of the power, influence, and links of these politicians. Therefore, they are also more likely to appoint politicians to the board and management rather than nominate candidates with appropriate professional qualifications. 
Table 6

Main regression results (PCSE) of Moderating Effect of Director Financial Expertise (Dependent Variable= ROE and 2200 Observations)

\begin{tabular}{|c|c|}
\hline Variables & ROE \\
\hline & Coefficient $\quad$ Z-Statistics \\
\hline Constant & $6.471 \quad(2.35)^{* *}$ \\
\hline POCON & $0.688 \quad(0.66)$ \\
\hline DEFs & $0.054 \quad(0.15)$ \\
\hline POCON × DEFs & $-1.102 \quad(-2.46)^{* *}$ \\
\hline LEVE & $-15.752 \quad(-21.49) * * *$ \\
\hline BIG 4 & $4.688 \quad(8.99)^{* * *}$ \\
\hline CMSize & $0.471 \quad(3.04)^{* * *}$ \\
\hline Industry Effect: & Included \\
\hline Year Effect: & Included \\
\hline $\mathrm{R}^{2}$ & 0.2988 \\
\hline
\end{tabular}

\section{Discussion}

This study's objective was to investigate the association between political connection and firm performance among non-financial Pakistan listed firms. This paper provides empirical evidence of how the political connections of non-financial firms impact their performance, with a moderating variable, i.e., director financial expertise. This study used Pakistan as an empirical setting for several reasons. First, Pakistan is perceived as a country with a high level of corruption, and poor corporate governance, thus it is pertinent for this study to share its findings, emphasising the importance of politically connected firms in the country's economic activities. Second, Pakistan is a country commonly known for its political connections and its effects on firm behaviour. It is pertinent to study the level of political connections to predict future firm behaviour. Saeed, Belghitar and Clark (2019) commented that it is essential to study Pakistan's political connections with firm behaviour. Experience has shown that many Pakistani firms are politically connected, and even highly placed political individuals like the prime minister have been involved. Third, related issues stem from political connection such as tax issues, corruption and access to credit markets affect Pakistan's economic growth. Hence, it is essential to study Pakistan's environment considering emerging market growth is significant in Asia.

Congruent with the previous studies (Faccio, 2010; Cheema et al., 2016; Sadiq et al., 2019; Aldhamari et al., 2020), the results of this study showed that political connection harms firm performance. Several researchers have implied that political connections are expected to assist firms in allocating credit and the procurement of government contracts. In contrast, others have predicted that political influence is for personal interest rather than companies' interest. Regardless, the result of this study raises an important question for future study related to what caused the negative relationship between politically connected firms and firm performance. So far, no affirmation answer to this question has been found as previous studies do not elaborate upon this concern. However, this study assumed politicians depend on the firms to support their political agenda, resulting in low firm performance. If this is so, stakeholders and the like should pay more attention and there should be regulatory control to lobbying contribution to the political parties. This paper suggests that the securities commission should regulate the involvement of politically connected firms. Also, political contributions should be regulated to monitor the misuse of power by the political parties.

In general, the management of the companies engaged politically connected directors on the board to utilise their links as external resources of the firm to enhance the performance. However, in emerging economies like Pakistan, the negative result of present study provide support of the argument that company management engaged politically connected directors to utilise the links of politically connected directors to achieve management's personal interests rather than to use these links in favour of company and majority shareholders. As a result, firm financial performance was unsatisfactory as political connections harmed firm performance. 
In an additional analysis, the study also found that the role of director's financial expertise was significant in a politically connected firm as this expertise impacted firm performance. The negative result of the interaction term of director financial expertise strengthened and gave furtherance to the impact of political connection in influencing ROE. One reason for this may be that the Pakistan code of corporate governance (2017) is silent about director financial expertise. Due to undefined policies, companies are taking advantage of the vague rules of corporate governance code to engage politically connected directors who do not have any financial expertise or qualifications. This study results support the argument that most political directors are in listed firms in Pakistan are not well educated, particularly in terms of financial expertise, and have poor managerial skills, which adversely affect the company's financial performance. As a result, minority shareholders and the company face troubles derived from their self-centred decisions.

\section{Conclusion}

The study investigated the impact of political connection on organisational performance in Pakistan. Contrary to the expectations, political connection in Pakistan was negatively associated with firm performance. The findings of this study support political theory, agency theory, and resource-based theory. This study advances the existing literature in two ways. First, the findings extend the literature in this area of interest. The finding that there are adverse effects of politically connected firms and firm performance in a weak regulated and poor governance country could be of use to study the trend of their non-financial firm performance. For example, financial institutions could use the findings to give credit to politically connected companies. Second, the result is unique. Although many studies have found otherwise, the inverse relationship between politically connected firms and firm performance implied that politically connected firms in Pakistan probably serve the personal interests of management rather than the interests of firms.

Like any other study, this research has limitations. One major limitation and challenge was the difficulty in collecting data because no Datastream database exists to collect information in Pakistan. This meant that data were manually collected. A second limitation was that this study was constrained to the ten-year period from 2008 to 2017. Other periods might have different results. Third, this study examined only non-financial firms.

In future studies, researchers should examine other dimensions such as female directors serving on the board, director remuneration, audit, and risk, as moderators on the relationship between POCON and firm performance. They also might consider financial firms. Lastly, researchers might consider other countries in Asia with different cultural and regulation.

\section{References}

Aldhamari, R., Nor, M. N. M., Boudiab, M., \& Mas'ud, A. (2020). The impact of political connection and risk committee on corporate financial performance: Evidence from financial firms in Malaysia. Corporate Governance: The International Journal of Business in Society, 20(7), 1281-1305. https://doi.org/10.1108/CG-04-2020-0122

Aluoch, M. O., Mwangi, C. I., Kaijage, E. S., \& Ogutu, M. (2020) The relationship between board structure and performance of firms listed at the Nairobi Securities Exchange. European Scientific Journal, 16(19), 337-364. https://doi.org/10.19044/esj.2020. v16n19p337

Arumona, J., Erin, O., Onmonya, L. \& Omotayo, V. (2019). Board financial education and firm performance: Evidence from the healthcare sector in Nigeria, Academy of Strategic Management Journal, 18(4), 1-14.

Bansal, N., \& Sharma, A. K. (2016). Audit committee, corporate governance and firm performance: Empirical evidence from India. International Journal of Economics and Finance, 8(3), 103-116. doi: 10.5539/ijef.v8n3p103

Berkman, H., \& Galpoththage, V. (2016). Political connections and firm value: An analysis of listed firms in Sri Lanka. Pacific Accounting Review, 28(1), 92-106. https://doi.org/10.1108/PAR-06-2014-0020

Bertrand, M., Kramarz, F., Schoar, A., \& Thesmar, D. (2007). Politicians, firms and the political business cycle: Evidence from France. Working paper, University of Chicago. Retrieved December 28, 2020, from http://www.crest.fr/ckfinder/userfiles/files/ pageperso/kramarz/politics_060207_v4.pdf

Bliss, M. A., \& Gul, F. A. (2012). Political connection and cost of debt: Some Malaysian evidence. Journal of Banking \& Finance, 36(5), 1520-1527. https://doi.org/10.1016/j.jbankfin.2011.12.011

Boubakri, N., Cosset, J. C., \& Saffar, W. (2012). The impact of political connections on firms' operating performance and financing decisions. Journal of Financial Research, 35(3), 397-423. https://doi.org/10.1111/j.1475-6803.2012.01322.x

Boudreau, J. W., Boswell, W. R., \& Judge, T. A. (2001). Effects of personality on executive career success in the United States and Europe. Journal of Vocational Behavior, 58(1), 53-81. https://doi.org/10.1006/jvbe.2000.1755

Buallay, A., Hamdan, A., \& Zureigat, Q. (2017). Corporate governance and firm performance: evidence from Saudi Arabia. Australasian Accounting, Business and Finance Journal, 11(1), 78-98. http://dx.doi.org/10.14453/aabfj.v11i1.6 
Chaney, P. K., Faccio, M., \& Parsley, D. (2011). The quality of accounting information in politically connected firms. Journal of Accounting and Economics, 51(1-2), 58-76. https://doi.org/10.1016/j.jacceco.2010.07.003

Cheema, M. U., Munir, R., \& Su, S. (2016). Political connections and organisational performance: evidence from Pakistan. International Journal of Accounting \& Information Management, 24(4), 321-338. https://doi.org/10.1108/IJAIM05-2016-0053

Ciftci, I., Tatoglu, E., Wood, G., Demirbag, M., \& Zaim, S. (2019). Corporate governance and firm performance in emerging markets: Evidence from Turkey. International Business Review, 28(1), 90-103. https://doi.org/10.1016/j.ibusrev.2018.08.004

De Andres, P., Garcia-Rodriguez, I., Romero-Merino, M. E., \& Santamaria-Mariscal, M. (2020). Politicians in disguise and financial experts on the board: Evidence from Spanish cajas. Business Research Quarterly, 1-18. [Online]. https://doi.org/ $10.1177 / 2340944420924417$

Dicko, S. (2016). Firms political connections and winning government contracts. International Journal of Economics and Finance, 8(2), 19-32. doi:10.5539/ijef.v8n2p19

Ding, S., Jia, C., Wu, Z., \& Zhang, X. (2014). Executive political connections and firm performance: Comparative evidence from privately-controlled and state-owned enterprises. International Review of Financial Analysis, 36, 153-167. https://doi.org/10.1016/j.irfa.2013.12.006

Erin, O., Arumona, J., Onmonya, L., \& Omotayo, V. (2019). Board financial education and firm performance: Evidence from the healthcare sector in Nigeria. Academy of Strategic Management Journal, 18(4), 1-14. [Online]. https://www.abacademies.org/articles/board-financial-education-and-firm-performance-evidence-from-the-healthcaresector-in-nigeria-8278.html

Ettredge, M., Li, C., Wang, Q., \& Xu, Y. (2019). Executive board member financial expertise and IPO performance. Accounting Horizons, HORIZONS-18-020. https:// doi.org/10.2308/HORIZONS-18-020

Faccio, M. (2006). Politically connected firms. American Economic Review, 96(1), 369-386. doi: $10.1257 / 000282806776157704$

Faccio, M., Masulis, R. W., \& McConnell, J. J. (2006). Political connections and corporate bailouts. Journal of Finance, 61(6), 2597-2635. https://doi.org/10.1111/j.1540-6261.2006.01000.x

Faccio, M. (2010). Differences between politically connected and non-connected firms: A cross-country analysis. Financial Management, 39(3), 905-928. https://doi.org/ 10.1111/j.1755-053X.2010.01099.x

Fan, J. P., Wong, T. J., \& Zhang, T. (2007). Politically connected CEOs, corporate governance, and post-IPO performance of China's newly partially privatised firms. Journal of Financial Economics, 84(2), 330-357. https://doi.org/10.1016/j.jfineco.2006.03.008

Francis, B. B., Hasan, I., \& Wu, Q. (2012). Do corporate boards affect firm performance? New evidence from the financial crisis. New Evidence from the Financial Crisis (April 12, 2012). Bank of Finland Research Discussion Paper No. $11 / 2012$. Available at SSRN: https://ssrn.com/abstract=2041194 or http://dx.doi.org/10.2139/ssrn.2041194

Güner, A. B., Malmendier, U., \& Tate, G. (2008). Financial expertise of directors. Journal of Financial Economics, 88(2), 323354. https://doi.org/10.1016/j.jfineco.2007.05.009

Habib, A., Ranasinghe, D., Muhammadi, A. H., \& Islam, A. (2018). Political connections, financial reporting and auditing: Survey of the empirical literature. Journal of International Accounting, Auditing and Taxation,31, 37-51. https://doi.org/10.1016/j.intaccaudtax.2018.05.002

Harjoto, M.A., Laksmana, I. \& Yang, Y.W. (2019). Board nationality and educational background diversity and corporate social performance, Corporate Governance, 19(2), 217-239. https://doi.org/10.1108/CG-04-2018-0138

Hair, J. F., Black, W. C., Babin, B. J., Anderson, R. E., \& Tatham, R. L. (2006). Multivariate data analysis (6 ${ }^{\text {th }}$ ed.). Pearson Prentice Hall.

Hamdan, A., Khamis, R., Anasweh, M., Al-Hashimi, M., \& Razzaque, A. (2019). IT governance and firm performance: $\begin{array}{lllllll}\text { Empirical Study } & \text { from } & \text { Saudi } & \text { Open, } 9(2) . & 1-8 & \text { [Online]. }\end{array}$ https://journals.sagepub.com/doi/full/10.1177/2158244019843721

Idris, F., Buchdadi, A., Muttaqien, M., \& Hariguna, T. (2020). The role of the board of directors with political connection for increasing the firm value. Accounting, 6(7), 1285-1290. doi: 10.5267/j.ac.2020.8.023

Irianto, D., \& Anugerah, N. (2018). The effect of financial expertise on compensation and board of directors turnover. Journal of Applied Managerial Accounting, 2(1), 51-64. https://doi.org/10.30871/jama.v2i1.718

Jackowicz, K., Kozłowski, Ł., \& Mielcarz, P. (2014). Political connections and operational performance of non-financial firms: New evidence from Poland. Emerging Markets Review, 20, 109-135. https://doi.org/10.1016/j.ememar.2014.06.005

Jaffar, R., \& Abdul-Shukor, Z. (2016). The role of monitoring mechanisms towards company's performance: Evidence from politically connected companies in Malaysia. Journal of Accounting in Emerging Economies,6(4), 408428. https://doi.org/10.1108/JAEE-05-2014-0021

Johl, S. K., Kaur, S., \& Cooper, B. J. (2015). Board characteristics and firm performance: Evidence from Malaysian public listed firms. Journal of Economics, Business and Management, 3(2), 239-243.

Juhmani, O. (2017). Corporate governance and the level of Bahraini corporate compliance with IFRS disclosure. Journal of Applied Accounting Research, 18(1), 22-41. https://doi.org/10.1108/JAAR-05-2015-0045 
Khan, M. Y. (2016). Corporate governance and cost of capital: Evidence from Pakistani listed firms [Doctoral dissertation, University of Glasgow]. Retrieved December 29, 2020, from http://theses.gla.ac.uk/7722/1/2016KhanPhD.pdf

Khwaja, A. I., \& Mian, A. (2005). Do lenders favor politically connected firms? Rent provision in an emerging financial market. Quarterly Journal of Economics, 120(4), 1371-1411. https://doi.org/10.1162/003355305775097524

Lashitew, A. A. (2014). The effect of political connections on credit access: does the level of financial development matter? Kyklos, 67(2), 227-254. https://doi.org/10.1111/ kykl.12051

Maaloul, A., Chakroun, R., \& Yahyaoui, S. (2018). The effect of political connections on companies' performance and value: Evidence from Tunisian companies after the revolution. Journal of Accounting in Emerging Economies, 8(2), 185-204. https://doi.org/10.1108/JAEE-12-2016-0105

Merendino, A., \& Melville, R. (2019). The board of directors and firm performance: empirical evidence from listed companies. Corporate Governance: The International Journal of Business in Society, 19(3), 508-551. https://doi.org/10.1108/CG-06-2018-0211

Osazuwa, N. P., Che-Ahmad, A., \& Che-Adam, N. (2016). Political connection, board characteristics and firm performance in Nigeria. In The European Proceedings of Social \& Behavioral Sciences (pp. 769-774). Retrieved December 29, 2020, from https://pdfs.semanticscholar.org/10fc/1b9a497d20f43d20bc6927c96f8d2614fc76.pdf

Sadiq, M., \& Othman, Z. (2017). Earnings manipulations in politically influenced firms. Corporate Ownership \& Control, 15(1), 65-71. https://doi.org/10.22495/cocv15i1art6

Sadiq, M., Mohamad, S., \& Kwong, W. C. G. (2019). Do CEO incentives mediate the relationship between political influences and financial reporting quality? International Journal of Asian Social Science,9(3), 276-284. https://econpapers.repec.org/article/ asiijoass/2019_3ap_3a276-284.htm

Saeed, A., Belghitar, Y., \& Clark, E. (2015). Political connections and leverage: Firm-level evidence from Pakistan. Managerial and Decision Economics, 36(6), 364-383. https://doi.org/10.1002/mde.2674

Saeed, A., Belghitar, Y., \& Clark, E. (2016). Do political connections affect firm performance? Evidence from a developing country. Emerging Markets Finance and Trade, 52(8), 1876-1891. https://doi.org/10.1080/1540496X.2015.1041845

Saeed, A., Belghitar, Y., \& Clark, E. (2017). Political connections and firm operational efficiencies: Evidence from a developing country. Review of Managerial Science, 11(1), 191-224. https://doi.org/10.1007/s11846-015-0185-5

Saeed, A., Belghitar, Y., \& Clark, E. (2019). Political connections and corporate performance: Evidence from Pakistan. Economics of Transition and Institutional Change, 27(4), 863-889. doi: 10.1111/ecot.12213

Saidu, S. (2019). CEO characteristics and firm performance: Focus on origin, education and ownership. Journal of Global Entrepreneurship Research, 9(29), 1-15. https://doi.org/10.1186/s40497-019-0153-7

Sarwar, B., Xiao, M., Husnain, M., \& Naheed, R. (2018). Board financial expertise and dividend-paying behavior of firms: New insights from the emerging equity markets of China and Pakistan. Management Decision, 56(9), 1839-1868. https://doi.org/10.1108/ MD-11-2017-1111

Shaw, T. S., Cordeiro, J. J., \& Saravanan, P. (2016). Director network resources and firm performance: Evidence from Indian corporate governance reforms. Asian Business \& Management, 15(3), 165-200. https://doi.org/10.1057/s41291-016-0003-1

Sokolov, V., \& Solanko, L. (2017). Political influence, firm performance and survival. Higher School of Economics Research Paper No. WP BRP 60/FE/2017. Available at SSRN: https://ssrn.com/abstract=3000367 or http://dx.doi.org/10.2139/ssrn.3000367

Swarnodeep, H. \& Aurelie, S. (2019). Do board expertise and networked boards affect environmental performance? Journal of Business Ethics, 158, 269-292. https://doi.org/10.1007/s10551-017-3769-y

Ujunwa, A., Salami, P. O., \& Umar, A. H. (2013). CEO duality and firm performance: An integration of institutional perceptive with agency theory. International Journal of Social, Management, Economics and Business Engineering, 7(1), 97-103. doi.org/10.5281/zenodo.1079418

Unsal, O. (2017). Political contributions and firm performance: Evidence from lobbying and campaign donations [Doctoral dissertation, The University of New Orleans]. Available at: https://scholarworks.uno.edu/td/2361

Van Horne, J. C., \& Wachowicz, J. M. (2005). Fundamentals of financial management. Pearson Education.

Wang, Y., Yao, C., \& Kang, D. (2018). Political connections and firm performance: Evidence from government officials' site visits. Pacific-Basin Finance Journal, 57, https://doi.org/10.1016/j.pacfin.2018.05.003

Wu, W., Wu, C., Zhou, C., \& Wu, J. (2012). Political connections, tax benefits and firm performance: Evidence from China. Journal of Accounting and Public Policy, 31(3), 277-300. https://doi.org/10.1016/j.jaccpubpol.2011.10.005

Yukl, G. (2012). Effective leadership behavior: What we know and what questions need more attention. Academy of Management Perspectives, 26(4), 66-85. https://doi.org/10.5465/ amp.2012.0088

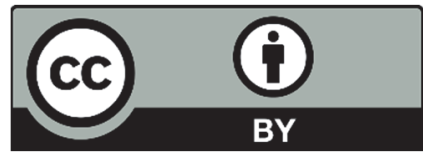

(C) 2021 by the authors; licensee Growing Science, Canada. This is an open access article distributed under the terms and conditions of the Creative Commons Attribution (CC-BY) license (http://creativecommons.org/licenses/by/4.0/). 